\title{
Giant cell tumour of first metacarpal bone
}

\author{
Mohammad Shahid, ${ }^{1}$ Manoranjan Varshney, ${ }^{1}$ Veena Maheshwari, ${ }^{1}$ Aysha Mubeen, ${ }^{1}$ Kavita Gaur, ${ }^{1}$ \\ Mohammad Siddiqui
}

1Department of Pathology, J.N. Medical College, Aligarh, Uttar Pradesh, India;

${ }^{2}$ Department of Radiodiagnosis, J.N. Medical College, Aligarh, Uttar Pradesh, India

Correspondence to Dr Kavita Gaur, kavgaur@gmail.com

\begin{abstract}
Summary
Giant cell tumour (GCT) or osteoclastoma is a benign locally aggressive tumour with a tendency for local recurrence. 85-90\% of cases occur in long bones; the sites most commonly affected being lower end of femur, upper end of tibia, lower end of radius and proximal humerus in descending order of frequency. Only $2 \%$ of GCT occurs in hand. GCT of bone accounts for $5 \%$ of all primary bone tumour. $80 \%$ of patients are above the age of 18 years, and it occurs commonly in adults between ages of 20 and 40 years. The authors report a case of GCT of first metacarpal which is very rare site for such tumour and only few cases reported in literature so far.
\end{abstract}

\section{BACKGROUND}

Gaint cell tumour (GCT) of metacarpal bone is rare.

\section{CASE PRESENTATION}

A 30-year-old male presented with the complaints of pain and swelling of her right thumb for the last 2 months. The swelling gradually increased in size, and there was a gross restriction of movements of the affected thumb. There was no history of trauma or any constitutional symptoms. On physical examination, there was a localised swelling over the right first metacarpal with variable consistency. The overlying skin was free, and the movements of the metacarpophalangeal and trapeziometacarpal joints were painful and restricted.

Radiographs revealed an expansile osteolytic lesion of the first metacarpal involving diaphysis with metaphyseal extension (figure 1A). Lateral radiograph of hand reveals multiloculated expansile osteolytic lesion with narrow zone of transition and evidence of comminuted pathological fracture involving first metacarpal with prominent adjacent soft tissue (figure 1B).

On the basis of these findings, differential diagnosis of GCT, aneurysmal bone cyst, enchondroma and fibrous dysplasia were made, fine needle aspiration cytology was done and a tentative diagnosis of GCT was made. Tumour was excised which grossly consisted of brownish cheesy material which had involved the entire metacarpal. Histopathological examination showed a well vascularised, highly cellular tissue consisting of stromal mononuclear cells and multinucleated giant cells present in close association with each other. Stromal cells were numerous, predominantly round to oval with foci of spindling, mild degrees of atypia and occasional mitosis (figure 2).

\section{OUTCOME AND FOLLOW-UP}

Patient was discharged in good conditions.

\section{DISCUSSION}

GCT of the bone is potentially malignant lesion despite presenting a benign picture microscopically. The comprise
$5 \%$ of all primary bone tumours. GCT is most commonly seen in the distal femur, the proximal tibia and the distal radius and the proximal humerus in descending order of frequency. ${ }^{1}$ GCT is uncommon in the small bones of hand and feet, and very few cases have been reported. GCT of first metacarpal is an uncommon finding and very few cases have been reported. The metaphyseal region of the metacarpals and phalanges is the site of origin for most of these tumours. ${ }^{2-4}$ The hand has limited free space and exquisite sensitivity, and even small masses can cause significant swelling, pain and disability.

Paget $^{5}$ and Coopers and Travers ${ }^{6}$ gave initial descriptions of GCT of bone. GCT of bone is a benign, but locally aggressive lesion. It is relatively rare tumour composed of connective tissue stromal cells and multinucleated giant cell that exhibit the phenotypic feature of osteoclast. ${ }^{7}$ The precise histogenesis of the tumour is unknown. It is commonly seen in long bones especially the femur (approximately $30 \%$ cases), tibia ( $25 \%$ cases), radius ( $10 \%$ cases) and humerus ( $6 \%$ cases). Involvement of spine and innominate bones are rare. ${ }^{7}$ They seldom occur in diaphyseal region of long bones. GCT of the bones of the hand are rare accounting for only $2 \%$ of cases and here phalangeal location of the tumour is more common than metacarpals. ${ }^{7}$ In a study done at Mayo Clinic over a 50-year period, only 13 GCTs involve the hand and only 3 involved the thumb. ${ }^{8}$ When present in the hand, they generally extend to the articular cartilage and are eccentrically located. ${ }^{9}$ GCT of the hand seems to represent a different lesion than conventional GCT in the rest of the skeleton. There is an 18\% incidence of multicentric foci indicating that a bone scan should be a part of routine workup of these tumours. ${ }^{10}$ Picci et al studied 326 cases of GCT and found only 6 histologically proven cases had an open epiphysial plate which accounted for $1.8 \%$ of their series. ${ }^{11}$ The tumour in our patient was unusual as it was located mainly at the diaphyseal region of the first metacarpal bone, and extend to the metaphyseal region. Differential diagnoses include aneurysmal bone cyst, simple bone cyst, fibrous dysplasia and enchondroma. The mean age of presentation of GCT is 32 


\section{BMJ Case Reports}

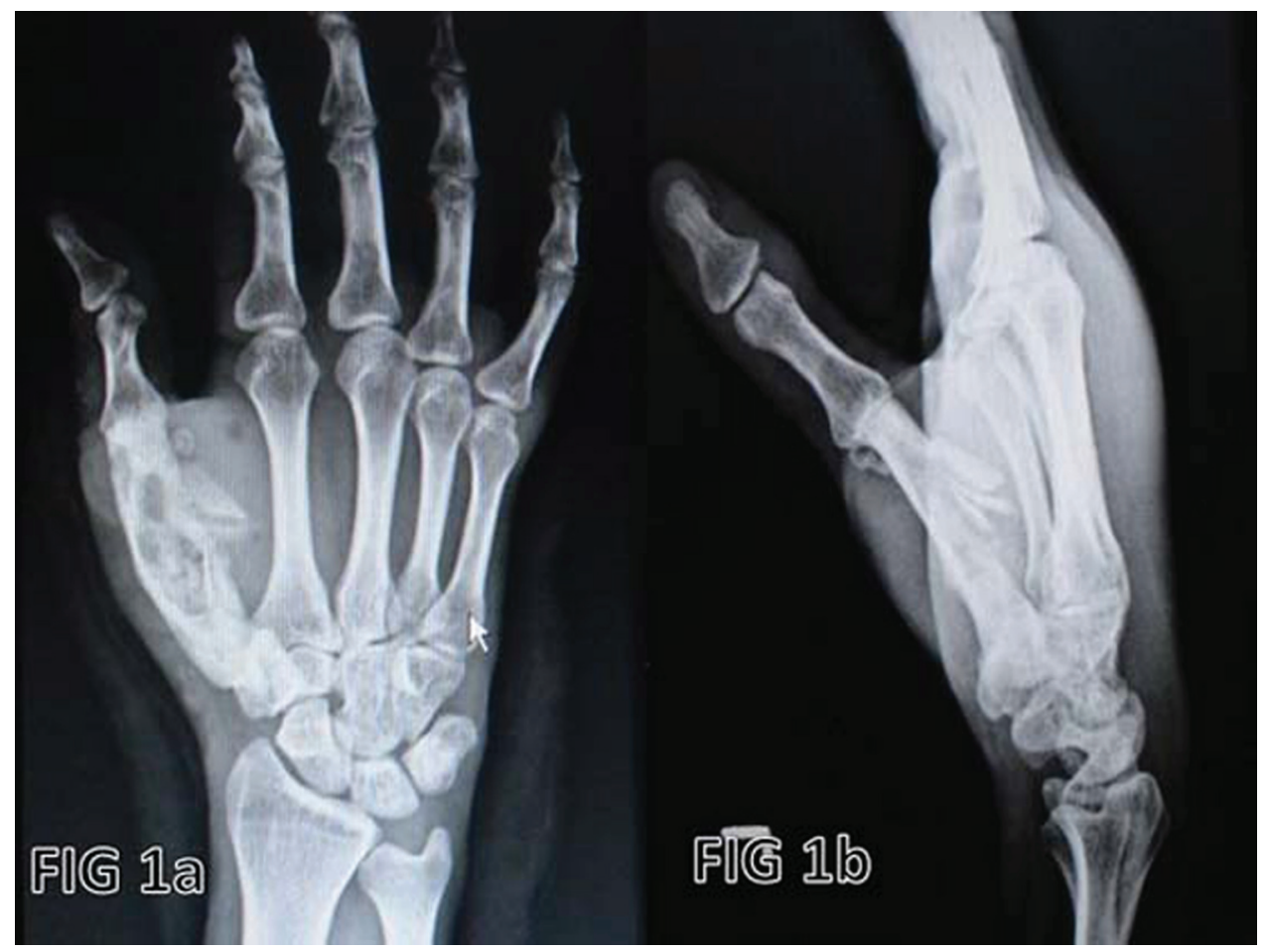

Figure 1 (A) Frontal radiographs revealed an expansile osteolytic lesion of the first metacarpal involving diaphysis with metaphyseal extension. (B) Lateral radiograph of hand reveals multiloculated expansile osteolytic lesion with evidence of comminuted pathological fracture involving first metacarpal with prominent adjacent soft tissue.

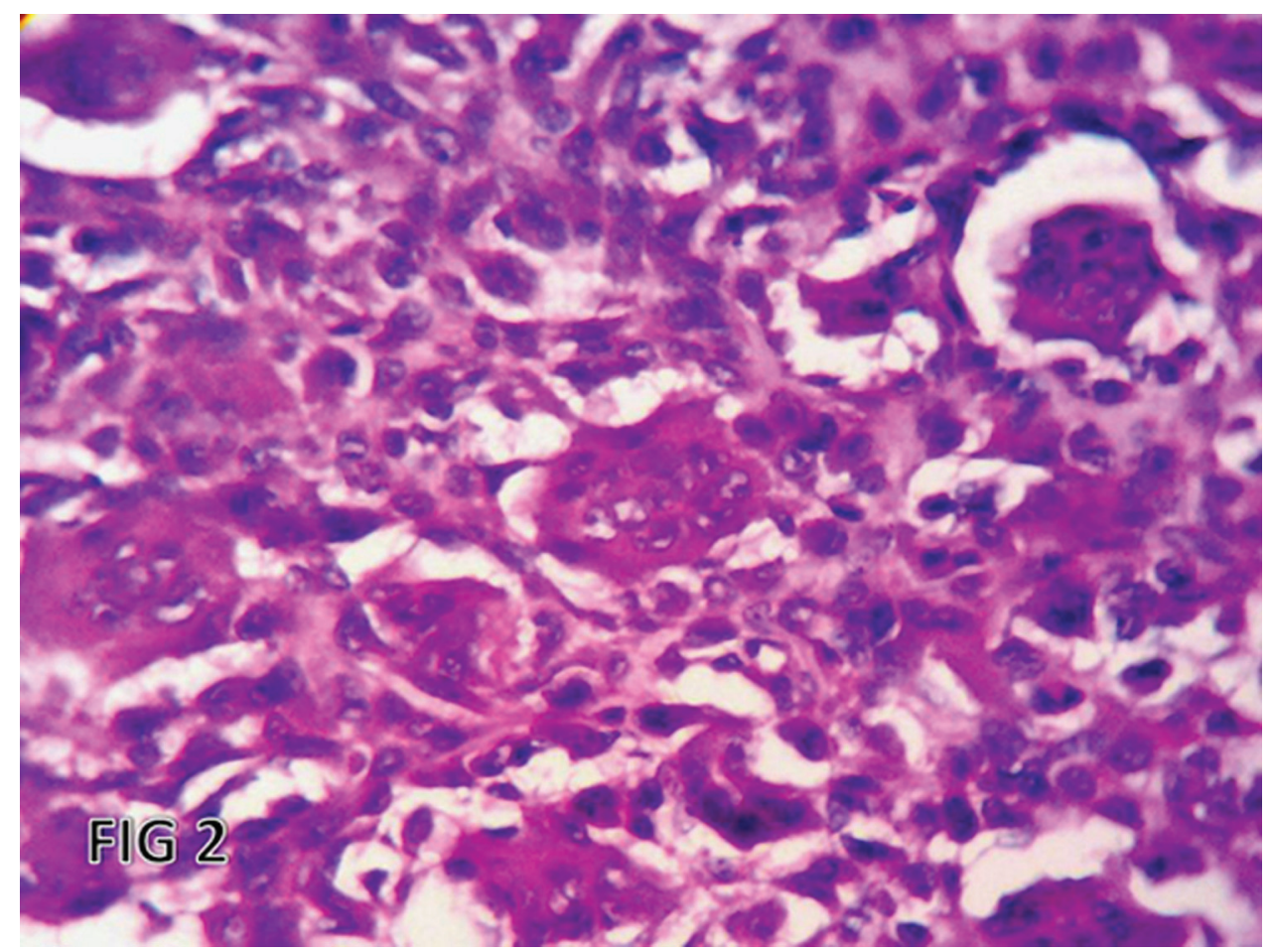

Figure 2 Section shows sheets of round, oval or elongated mononuclear cells evenly intermixed with numerous osteoclast-like giant cells $($ H\&E $\times 500)$.

years, whereas for hand it is even less (only 22 years). ${ }^{12}$ The extent of tumour at the time of diagnosis and the high recurrence rate following limited resection often dictate the need of an en bloc resection through normal tissue to prevent local recurrence. The standard treatment of GCT of bone traditionally has been intralesional excision of curettage and autograft reconstruction by packing the cavity of the excised tumour with morselised iliac cortical and 


\section{BMJ Case Reports}

cancellous bone. Intralesional excision, however, leaves microscopic disease in the bone regardless of how carefully or thoroughly performed. The reported incidence of local relapse with this technique is as high as $40-60 \% .^{13}$ There has been a great deal of effort expended on attempt to extend the curettage or excision by chemical or physical means. Chemicals such as phenol or cytotoxic agents like chlorpactin have been applied to the tumour bed to decrease the relapse with varying results. ${ }^{14}$ Cryosurgery using liquid nitrogen to extend the curettage has a high incidence of local wound and bone complications. Packing the tumour bed with methylmethacrylate has shown to decrease the relapse rate by generating local hyperthermia, which induces necrosis of any remaining neoplastic tissue. In addition, the polymerisation of methylmethacrylate may produce a local chemical cytotoxic effect. However, it is feared that the subchondral placement of cement may induce degeneration of the articular cartilage. There is a limited experience with the $\mathrm{CO}_{2}$ laser for cauterising the tumour bed. Although most recurrences of the GCT of bone can be expected within 2 years, some patients remain

\section{Learning points}

GCT is a locally aggressive tumour.

- It is rarely seen in metacarpal bones.

- Wide excision is better as local recurrence is common. at risk for a much longer period up to 19-30 years after curettage and bone grafting. ${ }^{14}$

\section{Competing interests None.}

Patient consent Obtained.

\section{REFERENCES}

1. Stoker DJ. Bone tumours (1): General characteristics benign lesions. In: Grainger RG, Allison DJ, eds. Diagnostic Radiology: A Textbook of Medical Imaging. Third edition. New York, NY: Churchill Livingstone 1997:629-1660.

2. Feldman F. Primary bone tumors of the hand and carpus. Hand Clin 1987;3:269-89.

3. Dahlin DC. Giant-cell-bearing lesions of bone of the hands. Hand Clin 1987:3:291-7.

4. Wold LE, Swee RG. Giant cell tumor of the small bones of the hands and feet. Semin Diagn Pathol 1984;1:173-84.

5. Paget J. Lectures on Surgical Pathology. Delivered at the Royal College of Surgeons of England. London: Longman, Brown, Green, and Longmans, 1853.

6. Coopers A, Travers B. Surgical Essays. Third edition. London: Cox \& Son 1818.

7. Goldenberg RR, Campbell CJ, Bonfiglio M. Giant-cell tumor of bone. An analysis of two hundred and eighteen cases. J Bone Joint Surg Am 1970;52:619-64.

8. Athanasian EA, Wold LE, Amadio PC. Giant cell tumors of the bones of the hand. J Hand Surg Am 1997;22:91-8.

9. Cornelis JP. Radiology of the Hand. New York, NY: Springer 1986:254-5.

10. Averill RM, Smith RJ, Campbell CJ. Giant-cell tumors of the bones of the hand. J Hand Surg Am 1980;5:39-50.

11. Picci $\mathbf{P}$, Manfrini M, Zucchi V, et al. Giant-cell tumor of bone in skeletally immature patients. J Bone Joint Surg Am 1983;65:486-90.

12. Yin Y, Gilula LA, Kyriakos M, et al. Giant-cell tumor of the distal phalanx of the hand in a child. Clin Orthop Relat Res 1995:200-7.

13. Carrasco CH, Murray JA. Giant cell tumors. Orthop Clin North Am 1989;20:395-405

14. Scully SP, Mott MP, Temple HT, et al. Late recurrence of giant-cell tumor of bone. A report of four cases. J Bone Joint Surg Am 1994;76:1231-3.

This pdf has been created automatically from the final edited text and images.

Copyright 2011 BMJ Publishing Group. All rights reserved. For permission to reuse any of this content visit

http://group.bmj.com/group/rights-licensing/permissions.

BMJ Case Report Fellows may re-use this article for personal use and teaching without any further permission.

Please cite this article as follows (you will need to access the article online to obtain the date of publication)

Shahid M, Varshney M, Maheshwari V, Mubeen A, Gaur K, Siddiqui M. Giant cell tumour of first metacarpal bone. BMJ Case Reports 2011;

10.1136/bcr.01.2011.3687, date of publication

Become a Fellow of BMJ Case Reports today and you can:

- Submit as many cases as you like

- Enjoy fast sympathetic peer review and rapid publication of accepted articles

- Access all the published articles

- Re-use any of the published material for personal use and teaching without further permission

For information on Institutional Fellowships contact consortiasales@bmjgroup.com

Visit casereports.bmj.com for more articles like this and to become a Fellow 